\title{
Global Infrastructure Gap: Theory and Realities of Ukrainian Agribusiness
}

\section{YAROSLAVA STOLIARCHUK, DENYS ILNYTSKYY, DMYTRO VOICHAK}

\begin{abstract}
This article deals with the generalization of the conceptual foundations of the global infrastructure gap theory as intercountry and interregional asymmetries in quantitative and qualitative parameters of economic activity infrastructural support development, which is implemented on the basis of agro-industrial complex. Forms of the global infrastructure gap are revealed and its conditionality by the lack of investments that do not take into account the principle of infrastructure escalation and logic of value chain infrastructure base of production processes development, is substantiated. It is proven that the differences in terms of technological development of countries and their disposition in terms of infratrajectories have to be supplemented by the institutional dimension in the system of infrastructure component of economic development's determinants. Based on the systematization of infrastructure functions in the economy, there are identified the key features of the global infrastructure of the agro-food market: service nature; dependence of market capacity on the level of infrastructure development; irregularity and asymmetry of development; the complexity of quantitative parameters determination; the need for faster growth in relation to the market.

The relevance of the article can be explained by the lack of scientific and analytical papers in the field of the institutional paradigm of the infrastructure of Ukrainian agrarian market, which economy continues to deepen the international specialization of the state in the manufacturing of agroindustrial complex products in terms of the deficit of investment into upgrading the quality of infrastructure. The current state of agricultural infrastructure of Ukraine in the view of agroindustrial exchanges activity, agricultural products wholesale markets, cooperatives, agrarian logistics from the perspective of the global infrastructure gap theory is analyzed in the article. There are revealed the key problems of development of domestic agro-food infrastructure - considerable difficulties with final products storage; lack of a clear profile of specialization; lack of material and technical base, information and advisory support; slow rates of forward, future's and option contracts; weak interest of traders and incompetence of producers; agrarian company executives' focus on shadow sector transactions to minimize tax payments and save financial resources. It is revealed that disproportions in terms of sufficiency of the main agricultural goods' production groups may lead to market structure shifts.
\end{abstract}

* This article was translated from its original in Ukrainian.

${ }_{1}^{1}$ Stoliarchuk Yaroslava Mykhailivna - Doctor of Economics, Professor at the Department of International Economics, Kyiv National Economic University named after Vadym Hetman. Sphere of scientific interests: global economic development and its asymmetries, the global financial market, international economic integration and transnationalization of national economies, international investment and innovation, the world labor market and international labor migration. E-mail address: stolyaroslava@ukr.net

Ilnytskyy Denys Alexandrovych - Doctor of Economics, Professor at the Department of International Economicsб Kyiv National Economic University named after Vadym Hetman. Sphere of scientific interests: knowledge economy, global scientific and educational space, information resources, intellectual property, economic infrastructure. E-mail address: ilnitskyd@gmail.com.

Voychak Dmytro Anatoliovych - PhD student at International Economics Department of Kyiv National Economic University named after Vadym Hetman. Sphere of scientific interests: globalization of markets, agrarian market infrastructure, global economic development, international trade, global food problem. E-mail address: voichak@ukr.net

IEP, № 31, (2019) pp. 119-145

(C) Yaroslava Stoliarchuk, Denys Ilnytskyy, Dmytro Voichak, 2019 «All rights reserved»

ISSN 1811-9832/2019/№ 2 (31) 
The strategic development priorities in the context of food security provision in the country and its integration into the European agro-food network are substantiated: realization of a range of institutional and regulatory measures, development of instruments for agro-logistics progress, budgetary and fiscal stimulus, qualitative improvement and resource filling of investment and financial infrastructure, creation of a field-specific agrarian bank and agroindustrial complex of loan guarantee fund in the structure of the banking system, improvement of technological innovation infrastructure and information support, etc.

KEY WORDS. agrarian infrastructure, global infrastructure gap, global infrastructure of agro-food market, agro-food chains, global competition, infra-path, infrastructure escalation, agroindustrial exchanges, wholesale markets of agricultural products, service cooperatives, agrarian logistics.

\section{Introduction}

The agroindustrial complex has traditionally been at the forefront of the national economy of Ukraine, which has been associated with agricultural specialization in the world for centuries. Only agrarian infrastructure, unlike other varieties, performs in the agroindustrial complex a clear dualistic role, acting as its independent and autonomous component, and integrates all its subsystems. This is what ensures their integrated functioning and inclusiveness, the formation of an institutional platform for the implementation of all types of inter-subject economic relations related to agricultural products. Solution of the global food problem is most often associated with the development of the agricultural market infrastructure at all levels from local to global.

The timeliness of the agricultural infrastructure research is underpinned by both: its important place in the structure of the domestic economy and the fact that the global economy faces the challenge of the significant capital investment need in the development of infrastructure of the world economy, which is estimated to reach USD 57 trillion by $2030^{2}$. However, according to experts of the World Economic Forum, the investment deficit in infrastructure development in the world economy will reach USD 1 trillion annually. In addition, according to experts, annual losses of profits of the global agrarian sector from the unsatisfactory state of logistics and infrastructure reach $50 \%$, and in Ukraine from 25 to $30 \%$ of the grown grain does not go to processing at $\mathrm{all}^{3}$.

\footnotetext{
${ }^{2}$ McKinsey Global Institute, Infrastructure Productivity: How to Save \$1 Trillion a Year, January 2013. - $100 \mathrm{p}$ https://www.mckinsey.com/ /media/McKinsey/Industries/Capital\%20Projects\%20and\%20Infrastructure/Our\%20In sights/Infrastructure\%20productivity/MGI\%20Infrastructure Full\%20report Jan\%202013.ashx

3 Dziubenko T. H. Ukrainian grains market infrastructure and logistics development (ukr. Rozvytok infrastruktury ta lohistyky zernovoho rynku Ukrainy) / T. H. Dziubenko // Ekonomika APK. 2014. No. 9. - p. 64. [In Ukrainian].
} 


\section{Problem situation}

Insufficient attention to the formation of effective models of functioning and development of infrastructure, as well as the lack of investments in this field have led to the fact that the current state of infrastructure in Ukraine is characterized by deep institutional and organizational and economic failures, the inability to provide objective pricing in the agrarian sphere all participants in agricultural production and unobstructed movement of agricultural products across all links of the food chain. This is deteriorating the food security situation in the country and the global economy as a whole, as Ukraine has a leading position in the global market for a number of food products.

The purpose of this paper is to identify key problems in the development of agrarian infrastructure of Ukraine and to substantiate the strategic priorities of its development through the lens of conceptual foundations of the theory of the global infrastructure gap.

\section{Theoretical bases of agrarian market infrastructure development}

The entry of the global economy into a path of sustainable balanced growth implies, among the priority tasks, the elimination of deep intercountry and interregional asymmetries in the quantitative and qualitative parameters of the development of infrastructural support for economic activity. For our country, this is an issue of particular importance given the extremely low level of development of infrastructure for economic activity in the field of agroindustrial complex, which was successfully demonstrated by R. Samet ${ }^{4}$. In general, the infrastructural stage of social development is consistently followed by industrial, distribution, information and environmental stages that determine the logic of development of national economic systems in the unity of their material base and superstructure. Thus, the global competitive leadership of the United States of America in recent decades has been based on a diversified theoretical framework, its implementation is taking place in national economic development policies. In particular, the well-known American School of Economics considered that the three key tenets are the national economic protectionism, the development of physical and financial infrastructure.

There is every reason to argue that local and global infrastructure plays its a role in the system of factors of endogenous and exogenous internationalization of national agroindustrial markets. Their hierarchy allowed further talk about infrastructure escalation. The international

${ }^{4}$ Samet R.H. Complexity science and theory development for the futures field // Futures, No. 44. Elsevier. 2012. - pp.504-513. 
team of researchers substantiated the key factors holding back the internationalization of agroindustrial markets (Table 1).

Table1

KEY BARRIERS FOR INTERNATIONALIZATION OF INTERNAL AGRO-FOOD MARKETS

\begin{tabular}{|c|l|c|l|}
\hline \multicolumn{2}{|c|}{ Product export barriers } & \multicolumn{2}{|c|}{ Product import barriers } \\
\hline 1 & Poor road infrastructure & 1 & Poor road infrastructure \\
\hline 2 & Poor storage infrastructure & 2 & Poor storage infrastructure \\
\hline 3 & $\begin{array}{l}\text { Weak cultivation, crop processing, } \\
\text { losses and poor quality }\end{array}$ & 3 & $\begin{array}{l}\text { The unwillingness of local consumers to } \\
\text { pay at the level of world market prices }\end{array}$ \\
\hline \multirow{2}{*}{4} & $\begin{array}{l}\text { Inability of small farmers to compete in } \\
\text { large markets }\end{array}$ & 4 & $\begin{array}{l}\text { Cultural preferences for specific } \\
\text { products and their diversity }\end{array}$ \\
\cline { 2 - 4 } & 5 & Insufficient local demand \\
\hline
\end{tabular}

Source: compiled by the authors according to: Ickowitz A. Agricultural intensification, dietary diversity, and markets in the global food security narrative / A. Ickowitz, B. Powell, D. Rowland, A. Jones, T. Sunderland // Global Food Security. No. 20, 2019. pp. 9-16.

The economic paradigm of infrastructure has been actively developing since the middle of 1950 s under the influence of dynamic diversification of economic activities, large-scale servicing of economic processes, and the outgrowth of the fourth technological framework of the narrow institutional framework of the production industrial mode. Thus, if A. Hirschman distinguished four features of infrastructure ${ }^{5}$ in 1958, then in the following decades its component composition expanded rapidly. Substantial identification of infrastructure as overhead capital has evolved in two conceptual directions: economic and social infrastructure. The complication of infrastructure content has led to the fact that in $1995 \mathrm{~K}$. Fosu distinguishes up to 11 components of agricultural infrastructure: irrigation and water access systems; transportation facilities; storage places; commercial infrastructure; manufacturing infrastructure; utilities; agricultural research and knowledge distribution; communication and information services; land-saving services; credit and financial institutions; medical and educational services ${ }^{6}$.

In turn, systematic processes of economic globalization, which have encompassed all structural subsystems of the world economy, form the prerequisites for the development of global infrastructure, through

\footnotetext{
${ }^{5}$ Hirschman, Albert O. The Strategy of Economic Development, Yale University Press, New Haven, CT. 1958. $230 \mathrm{p}$.

Fosu, K.Y. Public Goods and Services and Food Security: Theory and Modelling Approaches with Special Reference to Ghana and Burkina Faso / Fosu, K. Y., N. Heerink, K.E Jhoudo, M. Kuiper and A. Kuyvenhoven. Paper presented at SADACC Seminar, 13-15 March, 1995. Accra, Ghana. 46 p.
} 
which the involvement in the global value chains of those factors, industries, economic systems and national economies that are of interest to international business entities is occurred. It is no coincidence that the institutional development of global markets is characterized by a variety of institutions that fulfill infrastructure functions, including the distribution and exchange of goods. As global markets grow faster than many local markets, they exert considerable exogenous pressure on the development of organizational and technical infrastructure ${ }^{7}$.

It should be emphasized that the wide-ranging and multi-directional influence of individual elements of infrastructure on the development of national and regional economies made strong methodological foundations for the concept of critical infrastructure. It completed the theories that were traditionally used in market infrastructure research, namely: overhead costs, institutional, distribution, marketing, logistics theories. Now, the following institutional aspects of views on determination of the term of critical infrastructure are highlighted: academic, sectoral and governmental ${ }^{8}$. O. Williamson divided economic theory of infrastructure into two tangible paradigms - technological and institutional ${ }^{9}$, which, in our view, offers wide opportunities for a more complete and systematic analysis of national infrastructure systems and the driving forces behind their development.

The development of the theory of institutionalism and the emergence of the concept of infrastructure have become the answer of scientists to the causes of periodic crises in the most developed countries. The cyclical nature of economic development has often been explained by the fact that infrastructure and production, as inert sectors of the market, do not have time to respond to changes in consumption. Leadership in the global market is acquired by those entities that have been able to take advantage of technological and/or market opportunities. However, we recognize that infrastructure most often refers to the factors that create barriers to market promotion. This is probably why Swedish researchers have found that the activation of innovation in the agricultural sector of the economy is mainly explained by the factors that allow to solve existing problems of development, rather than technological or market opportunities ${ }^{10}$. From our point of view, the most important factors for enterprise problems are the society

${ }^{7}$ Kaira Z.S. Economic Geography: Theory and Practice (ukr. Rozmishchennia produktyvnykh syl: teoriia ta praktyka): navch . pos ibnyk / Z. Kaira. Donetsk: Alfa-pres, 2006. 320 p.

8 Jaradat R. Fragility of oil as a critical infrastructure problem. / R.M. Jaradat, C.B. Keating // International journal of critical infrastructure protection. 2014. No.7. pp.86-99.

9 Williamson O. Transaction Cost Economics and Organization Theory / Oliver Williamson // Journal of Industrial and Corporative Change. 1993. Volume 2, Issue 2. pp.107-156.

${ }_{10}$ Taalbi J. What drives innovation? Evidence from economic history /Josef Taalbi // Research Policy. No. 46. 2017. pp.1437-1453. 
demands, which are especially increasing as the provisions of the sustainable development concept are implemented.

Growth of networking should be seen as a key trend that outlines the importance of infrastructure for social and economic development and competitive leadership of global market players. Therefore, the theoretical foundations of the international networks' development (especially the eclectic paradigm of J. Dunning, the theory of global value chains and the theoretical platform of the "improved Uppsala model") should be one of the defining factors for the study of the infrastructure of global commodity markets. Many multinational enterprises are able to implement their benefits in development of the effective business models ${ }^{11}$.

Theories of market balance and international economic relations recognize the existence of a cyclical development of the principal players, which objectively affects the development of infrastructure. In particular, this led to the fact that in agriculture the total investment in fixed capital was almost halved in 1980-2007 in Greece. At that time, priority was given not to infrastructure development, but to the consumption and urban real estate, which eventually led to the crises ${ }^{12}$.

Investment in technological infrastructure development is an integral part of science, technology and innovation policy instruments in many theories. In particular, according to J. Schumpeter's growth theory, neoclassical, neo-Marshallian, systemic, institutional and evolutionary theories ${ }^{13}$.

Innovative development is often related to the consistent development of technological frameworks, the infrastructural dimension of which has not been given attention in science. The new concept of infra-trajectories is significantly revealing the role of infrastructure in shaping the markets of goods, produced according to a particular technology. It was proposed by Japanese researcher $M$. Hirooka as a result of the study of the evolution of key macro technologies ${ }^{14}$. The development of biotechnology, as the basic technology of the latest technological organization, is gaining importance with the need for an appropriate infrastructure. As the followers of M. Kondratiev, J. Schumpeter, and M. Hirooka have demonstrated, the stage of forming

\footnotetext{
${ }^{11}$ Rusak D. International Corporate Networks in Contemporary Geo-economic Environment (ukr. Mizhnarodni korporatyvni merezhi $v$ suchasnomu heoekonomichnomu prostori) : Monograph / Denys Rusak. Kyiv: ADEFUkraina, 2018. 408 p. [In Ukrainian].

12 Papageorgiou A. Agricultural equipment in Greece: Farm machinery management in the era of economic crisis // Agriculture and Agricultural Science Procedia: Farm Machinery and Processes Management in Sustainable Agriculture, 7th International Scientific Symposium. No. 7. 2015. Pp. 198 - 202.

${ }^{13}$ Laranja M. Policies for science, technology and innovation: Translating rationales into regional policies in a multi-level setting / M. Laranja, E. Uyarra, K. Flanagan // Research Policy. 2008. No. 37. Pp.823-835.

${ }_{14}$ Hirooka M. Innovation dynamism and economic growth: A nonlinear perspective. Edward Elgar Publishing, 2006. 448 p.
} 
a global market for biotechnology products has now begun ${ }^{15}$. Therefore, investments should be made at the national level to develop the infrastructure of markets in view of their technological dimension.

The theory of international competitiveness proves that well-planned, effectively operating in the conditions of globalization modern infrastructure always represents a significant competitive advantage of the national economy. Developed economies that have modernized efficient infrastructures are able, on competitive terms, to attract the best practitioners and dynamically developing companies in every sector of the economy. National models of enhanced infrastructure representation have their own features, but all come from an awareness of its role.

Therefore, modern global infrastructure is a complex of industries designed to ensure the effective functioning of all sectors of the world economy and to prevent developmental problems (on global, regional, market and sectoral levels). As one of the factors in solving the global food problem is the readiness of the infrastructure for provision of market relations related to agroindustrial complex products, the infrastructure of the global agrarian market is an essential component. The objectivity of the need for a functioning global agro-food market infrastructure is unavoidable, since food production cannot be stopped in view of the enormous risks of mass deaths from starvation or the decline to a dangerous state of health due to malnutrition, it is the most dangerous of all risks. The key features of global agro-food market infrastructure include:

- service nature;

- dependence of market capacity on the level of infrastructure development;

- unevenness and asymmetry of development;

- the complexity of quantitative parameters determination;

- the need for faster growth in relation to the market.

FAO experts are tending to the study of agricultural market infrastructure from the perspective of its effectiveness. In particular, as a set of components (wholesale, retail and purchasing markets, warehouses, etc.) that allow to minimize harvest losses, cost effective marketing and to minimize health risks ${ }^{16}$. Special attention should be paid to infrastructure institutions that perform complex functions (logistic centers, warehouses, wholesale markets, etc.). Global agro-food market infrastructure multifunctional institutions include terminal

15 Akaev A. Economic potential of breakthrough technologies and its social consequences. / A. Akaev, A. Rudskoi. in "Industry 4.0: Entrepreneurship and Structural Change in the New Digital Landscape". ed. T.Devezas, J.Leitao, A. Sarygulov. Springer. 2017. Pp.13-41.

${ }_{16}$ Marocchino C. A guide to upgrading rural agricultural retail markets / Cecilia Marocchino. UN Food and Agriculture Organization. 2009. 60 p. http://www.fao.org/fileadmin/user_upload/ags/publications/AGSF_WD_24.pdf 
markets, which on the one hand must be combined with suppliers, primary processing centers and with national and international agribusiness centers on the other hand. In particular, for example, in India, experts from the National Agrarian Marketing Institute counted up to 50 infrastructure sites in only one of the terminal markets ${ }^{17}$.

There are two key models of agro-food market infrastructure identification worldwide: 1) as a source of replenishment of budgets of various levels (especially for developing countries); 2) as a complex category that performs both fiscal and security functions, as well as social, cultural functions, regional development function, etc. In the second model, infrastructure is several times more deeply integrated into key social and economic processes. However, diversity is not conditioned only by the model. Different scientists, governments, and even international organizations, such as the World Health Organization and FAO, have different identifications of the agro-food market and its components ${ }^{18}$.

Often, infrastructure is viewed solely as a part of a manufacturing process and it may hold investment in its development. Systematization of infrastructure functions in the economy made it possible to identify following functions: territorial development, regulating, targeting, integration and support functions ${ }^{19}$. Thus, the integration function allows not only to shape the national market, but also its integration with the world market. Infrastructure functions are more specific in the agro-food market. In particular, it is about supply and demand balance; consumers provision with access to food products and the ability of food producers to sell goods; minimization the costs of handling and preservation of the product and its consumptive qualities; and traditional information and financial support for market entities and regulatory support ${ }^{20}$.

Institutions often act in the form of business enterprises in the agro-food market infrastructure system. Therefore, capital concentration processes are also inherent in institutions that perform infrastructure and intermediary functions. There are occurred the processes of concentration of infrastructure in the regional markets with different levels of maturity,

17 Intodia V. Investment in Agricultural Marketing and Market Infrastructure - A Case Study of Bihar. National Institute of Agricultural Marketing. Research Report. 2011-12. - 77 p. https://www.ccsniam.gov.in/ images/pdfs/Final_report_of Bihar_research_study.pdf

18 A guide $^{-}$to Healthy food Markets. World Health Organization. 2006. https://apps.who.int/iris/ bitstream/handle/10665/43393/9241593938_eng.pdf;jsessionid=DFBA9747A8A503B9EABE2F4527CA5C75?sequ ence $=1$; Food Outlook: Biannual report on global food markets. UN Food and Agrilculture Organization. http://www.fao.org/3/ca4526en/ca4526en.pdf; Rasmussen H. O. The Global Organic Food Market and Transformation. A Conceptual Theoretical Framework. 2008. 40 p. http://orgprints.org/14866/1/14866.pdf.

${ }^{19}$ Zhupanenko V. M. Modern Definition of Economic Infrastructure (ukr. Suchasne traktuvannia infrastruktury ekonomiky / V. M. Zhupanenko // Accounting and Finance in Agrobusiness (ukr. Oblik i finansy APK). 2010. No. 3. pp. 129-138. [In Ukrainian].

${ }^{20}$ Food resources market in the food security system of the Far East (rus. Rynok prodovolstvennykh resursov $v$ sisteme obespecheniya prodovolstvennoy bezopasnosti Dalnego Vostoka): monograph / A.V. Ulezko. L.L. Pashina. Voronezh: FGBOU VPO Voronezhskiy GAU. 2014. 291 p. [In Russian]. 
with varying intensity. So, the Chicago Mercantile Exchange acquired the Chicagoland Chamber of Commerce in 2006 and the New York Mercantile Exchange in 2008. In 2017, in the summer, the Indian Commodity Exchange and the National Multi-Commodity Exchange merged. The evolution of international commodity market leaders in agrarian products relies on the active use of ICT-based networking and contractual networks. In particular, access to Chicagoland Chamber of Commerce trading is available in 150 countries, through a network of 11 global hubs and 12 partner exchanges.

\section{Global infrastructure gap}

The world agro-food system was formed as a result of the development of international specialization and cooperation in the field of production, circulation and consumption of food. Its development not only eliminates, but also contributes to the uneven development of national food systems, because of the fact that the internationalization of economic relations continues. Its leading link is the developed countries for which foreign markets are becoming one of the main drivers of economic growth, which is reflected in the further deepening of specialization and cooperation in food production, resource circulation, mutual strengthening of the movement of capital and technology.

The unevenness of development of global agro-food market and the market itself creates a space of opportunity in which business structures are the most active actors. Multinational enterprises are joining the key segments of infrastructure development. Western researchers argue that multinational enterprises create global infrastructure systems that are endless in the scale of interaction ${ }^{21}$ and are of particular importance for the development of innovative processes ${ }^{22}$ and marketing infrastructure ${ }^{23}$.

The methodology of the world-system theory allows the stratification of countries in terms of infrastructure development into three groups - the center (their institutions are capable of providing infrastructure for a strong economy), the semi-periphery and the periphery (their weak institutions do not support the development of infrastructure) ${ }^{24}$. In particular, this can be seen from the countries' position on the Logistics Productivity Index (Table. 2). This suggests that against the background of global integration in the world there is a global infrastructure gap, which means the accumulation of differences in the levels of infrastructure

\footnotetext{
${ }^{21}$ Rays M. Borders of borderless enterprises (rus. Granitsy bezgranichnykh predpriyatiy) / M. Rays // Problems of management theory and practice (rus. Problemy teorii i praktiki upravleniya). 1997. No. 1, pp. 92-97. [In Russian].

${ }_{22}$ Works, alliances and partnerships in the innovation progress. S. de la Mothe, A.Link (eds). Boston, $2002.312 \mathrm{p}$

${ }^{23}$ Networks and markets. S.Rauch, A.Cassella (eds). N.Y., 2001. 346 p.

${ }^{24}$ Gunaratne S. A. Prospects and limitations of world system theory for media analysis: The Case of the Middle East and North Africa // Gazette. vol. 63(2-3). Pp. 121-148.
} 
development of the countries of the world, which causes more significant differences in the levels of social and economic development and quality of life of the population and economic agents of countries.

Table 2

\section{DYNAMICS OF COUNTRIES' POSITIONS ACCORDING TO THE LOGISTICS PRODUCTIVITY INDEX}

\begin{tabular}{|c|c|c|c|c|c|c|c|c|c|}
\hline \multirow{2}{*}{\begin{tabular}{|c|} 
level of \\
infrastructure \\
development
\end{tabular}} & \multirow{2}{*}{ Country } & \multicolumn{2}{|c|}{2018} & \multicolumn{2}{|c|}{2014} & \multicolumn{2}{|c|}{2010} & \multicolumn{2}{|c|}{2007} \\
\hline & & mark & rank $\downarrow$ & Mark & rank & mark & rank & mark & rank \\
\hline \multirow{10}{*}{ high } & Germany & 4.37 & 1 & 4.32 & 1 & 4.34 & 1 & 4.19 & 3 \\
\hline & Japan & 4.25 & 2 & 4.16 & 7 & 4.19 & 5 & 4.11 & 6 \\
\hline & Sweden & 4.24 & 3 & 4.09 & 9 & 4.03 & 10 & 4.11 & 5 \\
\hline & Netherlands & 4.21 & 4 & 4.23 & 3 & 4.25 & 2 & 4.29 & 1 \\
\hline & \begin{tabular}{|l|} 
Austria \\
\end{tabular} & 4.18 & 5 & 3.64 & 25 & 3.68 & 21 & 4.06 & 8 \\
\hline & Singapore & 4.06 & 6 & 4.28 & 2 & 4.22 & 4 & 4.27 & 2 \\
\hline & USA & 4.05 & 7 & 4.18 & 5 & 4.15 & 7 & 4.07 & 7 \\
\hline & United Kingdom & 4.03 & 8 & 4.16 & 6 & 3.95 & 16 & 4.05 & 10 \\
\hline & Switzerland & 4.02 & $\mathbf{9}$ & 4.04 & 11 & 4.17 & 6 & 4.13 & 4 \\
\hline & United Arab Emirates & 4.02 & 10 & 3.70 & 21 & 3.81 & 17 & 3.80 & 18 \\
\hline \multirow{10}{*}{$\begin{array}{c}\text { above } \\
\text { average }\end{array}$} & Italy & 3.85 & 18 & 3.78 & 19 & 3.72 & 20 & 3.52 & 23 \\
\hline & China & 3.75 & 20 & 3.67 & 23 & 3.54 & 27 & 3.20 & 30 \\
\hline & Canada & 3.75 & 21 & 4.05 & 10 & 4.03 & 11 & 3.95 & 12 \\
\hline & Korea & 3.73 & 22 & 3.79 & 18 & 3.62 & 23 & 3.44 & 25 \\
\hline & Czech Republic & 3.46 & 26 & 3.29 & 36 & 3.25 & 34 & 3.00 & 36 \\
\hline & Israel & 3.33 & 28 & 3.11 & 45 & 3.60 & 24 & 3.00 & 37 \\
\hline & Hungary & 3.27 & 30 & 3.18 & 40 & 3.08 & 38 & 3.12 & 33 \\
\hline & Turkey & 3.21 & 33 & 3.53 & 27 & 3.08 & 39 & 2.94 & 39 \\
\hline & Poland & 3.21 & 35 & 3.08 & 46 & 2.98 & 43 & 2.69 & 51 \\
\hline & Slovakia & 3.00 & 48 & 3.22 & 37 & 3.00 & 42 & 2.68 & 52 \\
\hline \multirow{10}{*}{$\begin{array}{c}\text { below } \\
\text { average }\end{array}$} & Latvia & 2.98 & 49 & 3.03 & 51 & 2.88 & 49 & 2.56 & 58 \\
\hline & Romania & 2.91 & 51 & 2.77 & 64 & 2.25 & 99 & 2.73 & 50 \\
\hline & Russian Federation & 2.78 & 61 & 2.59 & 77 & 2.38 & 83 & 2.23 & 93 \\
\hline & Bulgaria & 2.76 & 64 & 2.94 & 53 & 2.30 & 94 & 2.47 & 64 \\
\hline & \begin{tabular}{|l|} 
Kazakhstan \\
\end{tabular} & 2.55 & 81 & 2.38 & 106 & 2.66 & 57 & 1.86 & 137 \\
\hline & \begin{tabular}{|l} 
Syria \\
\end{tabular} & 2.51 & 82 & 2.08 & 144 & 2.45 & 75 & 1.91 & 131 \\
\hline & Armenia & 2.48 & 86 & 2.38 & 107 & 2.32 & 92 & 1.78 & 143 \\
\hline & Turkmenistan & 2.23 & 117 & 2.06 & 146 & 2.24 & 101 & & \\
\hline & Senegal & 2.22 & 118 & 2.30 & 116 & 2.64 & 59 & 2.09 & 108 \\
\hline & Ukraine & 2.22 & 119 & 2.65 & 71 & 2.44 & 79 & 2.35 & 74 \\
\hline
\end{tabular}

Source: compiled according to: Connecting to Compete 2018: Trade Logistics in the Global Economy. The Logistics Performance Index and Its Indicators. ed. Jean-Franzois Arvis etc. The International Bank for Reconstruction and Development, The World Bank. 2018. 82 p. URL: https: / / openknowledge.worldbank.org/bitstream/ handle/10986/29971/LPI2018.pdf. 
There is an increasing number of arguments for the impact of the level of infrastructure development on the key aspects of the economic development of national economies and regions. Thus, there is a positive correlation between the infrastructure development index and GDP per person (Fig. 1). Therefore, countries can be stratified into 4 clusters: 7 countries have a high level of infrastructure development, 48 countries are above average, 70 countries are below average, 23 countries have a low level. A similar result is given by the data of the infrastructure component of the Global Competitiveness Index ${ }^{25}$ (the first group - 9 countries, the second group - 25, the third group - 42, the fourth group - 61). The analysis of trade flows revealed that the nodes of the global agricultural products value-added trade network are Germany, USA, China, Japan, Netherlands, Spain, Italy, France, United Kingdom. Brazil, Saudi Arabia, Russia, Serbia ${ }^{26}$.

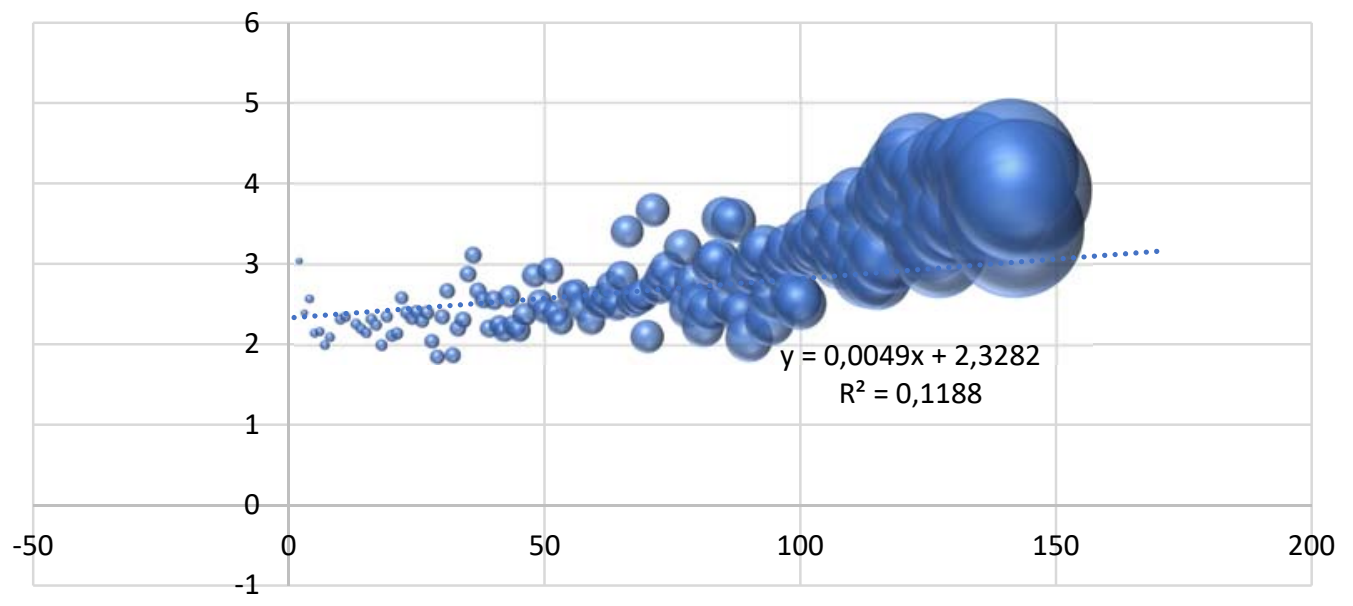

Fig. 1. The interconnection between the index of infrastructure development and GDP per capita

Source: compiled according to: Logistics Performance Index Dataset. World bank. 16-05-2019. URL: https: / /lpi.worldbank.org/sites/default/files/International_LPI_from_2007_to_2018.xlsx.

Although a recognized model of the interconnection between investment in infrastructure development and economic growth has not yet been established, in developed countries, the infrastructure is seen as the basis and the catalyst of the growth. Thus, at the end of the

25 The Global Competitiveness Index 2018. World Economic Forum. URL: http://www3.weforum.org/ docs/GCR2018/05FullReport/TheGlobalCompetitivenessReport2018.pdf

${ }^{26}$ Shepherd B. Infrastructure, trade facilitation, and network connectivity in Sub-Saharan Africa / B. Shepherd // Journal of African Trade. 2016. 3. Pp. 1-22. 
twentieth century in developed countries, the proportion is set at $1 \%-$ an increase in the aggregate cost of infrastructure leads to a corresponding increase in GDP ${ }^{27}$.

Infrastructure investments have a multiplier effect. This is why investment in rural infrastructure development is referred to by many researchers as a double-win strategy - at the same time, agro-industrial complex productivity is rising and poverty is falling, and the gap between countries is closing. However, different access to the global market capital limits countries' ability to make such investments.

The systematization of the varieties of infrastructure institutions made it possible to outline a certain sequence of their development. There is about infrastructure escalation, as the sequence and hierarchy of development of individual components of the agro-food market infrastructure - the development of physical infrastructure must precede the development of soft infrastructure, access - accessibility, road infrastructure - increased access to the market, finance and development of service institutions; information infrastructure analytical infrastructure. In the agricultural value chain, production must outpace trade and exchange, and then the focus should be on local value added. In many countries, in particular, the availability and accessibility of agro-food market infrastructure has been called as one of the most important drivers of competitive advantage in agricultural value chains by the World Bank experts ${ }^{28}$.

Road network density is one of the determinants of citizens' wellbeing and one of the first in the hierarchy of agro-food market infrastructure components. Thus, economic and mathematical modeling revealed that an increase in average road length per capita by $1 \%$ in China leads to an increase in household consumption by $0.08 \%{ }^{29}$. Other countries (USA, Brazil, Ethiopia and Nepal) have similar patterns.

The digital gap and digitization, as one of the world's leading trends that have an infrastructure base, can be seen in the agroindustrial complex development. In particular, it is understood that smart farming involves the widespread use not only of development and research achievements in the latest plant and animal varieties, but also the use of modern ICTs in current activity and management. Examples of successful smart sensing and monitoring, analysis,

${ }^{27}$ Satish P. Rural Infrastructure and Growth: An Overview. / P. Satish // Indian Journal of Agricultural Economy. Jan.-March 2007. Vol. 62, No.1. Pp.32-51.

${ }^{28}$ Warner M. Market-oriented agricultural infrastructure: appraisal of public-private partnerships / M. Warner, D. Kahan, S. Lehel // Agricultural Management, Marketing and Finance: Occasional Paper. FAO. 2009. No. 23. $185 \mathrm{p}$.

29 Jalan J., Ravallion M. Geographic poverty traps? A micro model of consumption growth in rural China / J. Jalan, M. Ravallion // Journal of Applied Econometrics. 2002. 17(4). Pp. 329-346. 
planning and control, and the use of cloud technologies are already common $^{30}$.

Scientific, technological and innovation policies, while in constant dialectical interconnection, largely determine the development of virtually all types of infrastructure. The inability of more countries around the world to effectively invest sufficient funds in R\&D and infrastructure leads to a widening gap between civilizations. Elimination of this gap is possible if the less developed countries repeat the path that the more developed countries have overcome. First of all, it is the institutionalization of state support for science and $\mathrm{R} \& \mathrm{D}$; secondly it is the internationalization and emphasis on competitive models of extended representation, and thirdly it is the provision of effective interconnections of economic agents.

\section{State of agrarian infrastructure of Ukraine}

At present, the domestic agroindustrial complex produces over $10 \%$ of Ukraine's GDP, provides about $40 \%$ of the inflow of foreign currency earnings $^{31}$ and $95 \%$ of food products consumed by the local population ${ }^{32}$. In recent decades, the dynamics of the share of production of agricultural raw materials and processing sectors in the GDP of Ukraine has been characterized by cyclicality. In particular, in the period of 2000-2007 it decreased from $30.9 \%$ of GDP (UAH 54.3 billion) to $15.2 \%$ (UAH 109.9 billion), but further increased to 27.5\% (UAH 544.2 billion). in 2015, but with a further cyclical fall to 23.7\% (UAH 707.8 billion) in 2017 (Fig. 2). This demonstrates both the low diversification of the economy and the active search for domestic niche producers in a dynamic global market. This has led to a significant increase in the recent years of Ukraine's international agrarian specialization in the system of international division of labor and a significant deindustrialization of the domestic economy. An extremely non-diversified structure causes a loss of resistance to the fluctuating global raw materials markets and sustainable development opportunities.

An increase in the absolute volume of agroindustrial complex products export as a result of the strengthening of agrarian specialization of Ukraine is not accompanied by proper development of its infrastructure. Moreover, the elimination of the state system of agricultural product contracting since

\footnotetext{
${ }^{30}$ Wolfert S. Big Data in Smart Farming - A review / S. Wolfert, L. Ge, C. Verdouw, M.-J. Bogaardt // Agricultural Systems. 2017. No. 153. Pp. 69-80.

${ }^{31}$ Maslak O. Agroindustry Budgeting - 2017 (ukr. Biudzhetuvannia ahrovyrobnytstva - 2017) / O. Maslak // Propozytsiia. 07.01.2017. http://propozitsiya.com/ua/byudzhetuvannya-agrovyrobnyctva-2017 [In Ukrainian].

32 Odnoroh M. A. Investment provisioning in agricultural sector of Ukrainian economy (ukr. Investytsiine zabezpechennia u silskohospodarskomu sektori ekonomiky Ukrainy) / M. A. Odnoroh // Naukovyi visnyk Polissia. 2016. No. 4 (8). Ch. 1. p. 144. [In Ukrainian].
} 
the first years of Ukraine's independence revealed significant institutional, organizational and economic failures of the domestic agricultural infrastructure. It demonstrates the practical inability to ensure not only the transparent interaction of agroindustrial complex participants and the unimpeded movement of agricultural products along the food chain links, but also the objective pricing in the agricultural sector and, consequently, the increase of incomes and profits of domestic agrarians. However, it is the agricultural infrastructure that aims to form established channels of ensuring the competitiveness of the domestic agroindustrial complex, on the one hand, as a material and technical basis for the functioning of agricultural markets, and on the other, as an organizational and economic mechanism for ensuring transparent and sustainable commodity and monetary circulation ${ }^{33}$. It covers the whole range of marketing, credit, financial, scientific, technical and innovative support for public representation of agricultural products both at national and international levels.

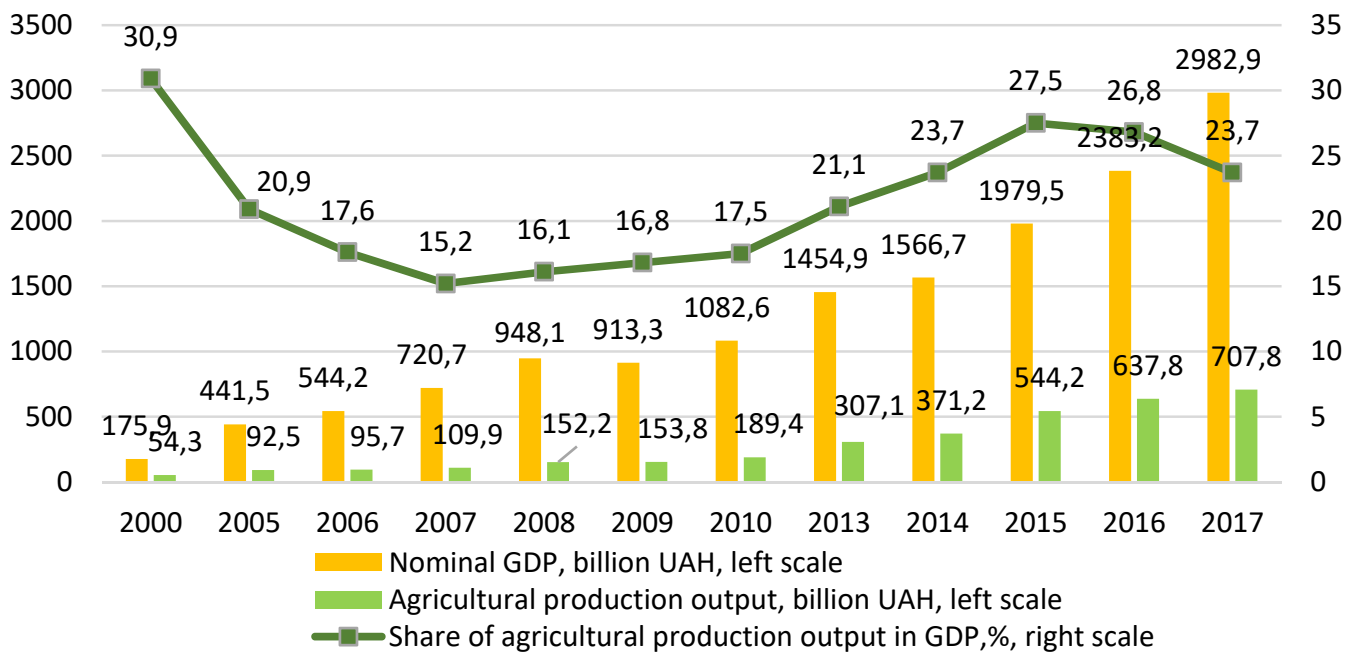

Fig. 2. Nominal GDP, agricultural production output and its share in the GDP of Ukraine in 2000-2017

Source: compiled according to: Agriculture of Ukraine in 2009. Statistical collection. State Statistics Committee of Ukraine. K., 2010. p. 38; Agriculture of Ukraine in 2017. Statistical collection. State Statistics Service. K., 2018. p. 37; Gross domestic product. Ministry of Finance. https://index.minfin.com.ua/en/economy/gdp/[In Ukrainian].

${ }^{33}$ Kravchuk N. I. Infrastructural background for ensuring the competitive development of the agricultural production (ukr. Infrastrukturne zabezpechennia konkurentospromozhnosti silskohospodarskoho vyrobnytstva / N. I. Kravchuk // Stalyi rozvytok ekonomiky. Mizhnarodnyi naukovo-vyrobnychyi zhurnal. 2013. No. 4 (21). p. 227. [In Ukrainian]. 
Agrarian exchanges, perhaps, are the most advanced institutional of regular trading form of standardized agricultural products, localized, as a rule, in large agricultural, industrial and commercial centers with developed communication and infrastructure networks. The absolute, almost ninefold increase in the number of exchanges registered in Ukraine in 1996-2015 (from 64 to 555) was ensured mainly by an increase in the number of commodity and commodities and raw materials exchange - from 28 to 391 and universal exchanges - from 22 to 104 respectively. However, the share of agroindustrial exchanges in their structure remains low and does not exceed $4.3 \%$. This indicates a significant lag in the pace of development of trade on agricultural exchanges from the overall rate of growth of commodity circulation and the very low level of use of their infrastructure capabilities, as well as the need for their quality development in the domestic agricultural sector.

Confirmation of the weak realization in Ukraine of the potential of the infrastructural capacities of the agroindustrial exchanges is the dynamics and consistency of the volumes of the realized deals (Table. 3). Unfortunately, the sharp increase in the volume of agricultural product exchange trade in 2011-2012 was caused not by objective factors, but by the influence of the state regulatory measures. This caused a sharp fall after the change in regulatory conditions. There have been no major changes in recent years.

Modern quantitative and qualitative parameters of functioning of agroindustrial exchanges are significantly inferior to international practice, which testifies practical absence of full exchange turnover of agricultural products, a significant lack of local concentration of demand and supply and lack of highly efficient organization of trading operations in Ukraine. The key reasons for slowing down large-scale development and diversification in according to the structure of the agricultural exchange trading segment are:

- significant difficulties with the storage of final products;

- lack of a clear profile of specialization;

- significant lack of material and technical base as well as information and advisory support;

- slow rates of forward, futures and option contracts;

- weak interest of traders and incompetence of producers;

- targeting of the executives of the agrarian company on shadow sector operations to minimize tax payments and save financial resources.

The relatively new institutional form of the agro-food market infrastructure in Ukraine is the wholesale markets for agricultural products. About UAH 1 billion was invested in their construction by 
private investors ${ }^{34}$, UAH 365 million of which was compensated from the state budget. The status of such institutions was given to 12 entities in 10 regions of Ukraine, but in reality, only two operate - the wholesale markets "Stolychnyi" in Kyiv and "Shuvar" in Lviv. Unfortunately, the "Hospodar" market (Donetsk) is partially destroyed and is not functioning, because it is located on a temporarily occupied territory, and "Azovskyi" (Mariupol) is located near the demarcation line and therefore has low turnover, low load of sale space and a lack of wholesale buyers. However, these wholesale markets are perspective because according to their structural, functional, organizational and technological characteristics for the reception and maintenance of cargo flows, they are most suitable for the needs of medium and large agricultural producers.

Table 3

STRUCTURE OF AGREEMENTS, CONCLUDED ON THE EXCHANGE OF UKRAINE BY TYPE OF GOODS, \%

\begin{tabular}{|c|c|c|c|c|c|c|c|c|c|}
\hline \multirow{2}{*}{ year } & \multicolumn{2}{|c|}{$\begin{array}{c}\text { agricultural } \\
\text { products }\end{array}$} & \multicolumn{2}{c|}{$\begin{array}{c}\text { food } \\
\text { commodities }\end{array}$} & $\begin{array}{c}\text { motor } \\
\text { vehicles }\end{array}$ & fuel & $\begin{array}{c}\text { real } \\
\text { estate }\end{array}$ & $\begin{array}{c}\text { other } \\
\text { goods }\end{array}$ & $\begin{array}{c}\text { total, } \\
\text { million } \\
\text { UAH }\end{array}$ \\
\cline { 2 - 11 } & $\begin{array}{c}\text { million } \\
\text { UAH }\end{array}$ & $\%$ & $\begin{array}{c}\text { million } \\
\text { UAH }\end{array}$ & $\%$ & & & & & \\
\hline 1995 & 220.8 & 41.4 & 5.1 & 1.0 & 7.5 & 0.5 & 48.2 & 1.4 & $\mathbf{5 3 2 . 9}$ \\
\hline 1997 & 42.2 & 0.6 & 42.0 & 0.6 & 1.8 & 0.3 & 11.8 & 85.0 & $\mathbf{7 1 5 7 . 1}$ \\
\hline 2000 & 989.7 & 45.8 & 62.8 & 2.9 & 8.9 & 13.4 & 17.6 & 11.3 & $\mathbf{2 1 6 2 . 0}$ \\
\hline 2002 & 6526.1 & 70.4 & 39.6 & 0.4 & 3.4 & 20.9 & 2.4 & 2.5 & $\mathbf{9 2 7 0 . 5}$ \\
\hline 2004 & 9098.4 & 68.5 & 376.3 & 2.8 & 2.7 & 17.3 & 1.9 & 6.7 & $\mathbf{1 3 2 7 8 . 9}$ \\
\hline 2006 & 11905.2 & 51.1 & 754.3 & 3.2 & 1.7 & 36.4 & 2.0 & 5.7 & $\mathbf{2 3 3 1 3 . 3}$ \\
\hline 2008 & 40019.5 & 71.3 & 751.1 & 1.3 & 0.7 & 22.1 & 0.9 & 3.7 & $\mathbf{5 6 1 2 2 . 4}$ \\
\hline 2010 & 43787.4 & 85.1 & 2272.3 & 4.4 & 0.4 & 5.1 & 0.5 & 4.5 & $\mathbf{5 1 4 4 0 . 6}$ \\
\hline 2011 & 63361.4 & 67.1 & 20139.9 & 21.3 & 0.1 & 8.0 & 0.3 & 3.2 & $\mathbf{9 4 4 2 0 . 0}$ \\
\hline 2012 & 77889.6 & 65.7 & 28541.8 & 24.1 & 0.0 & 5.3 & 0.7 & 4.1 & $\mathbf{1 1 8 5 4 4 . 4}$ \\
\hline 2013 & 11631.6 & 40.4 & 245.2 & 0.9 & 0.2 & 38.6 & 1.9 & 18.0 & $\mathbf{2 8 8 0 7 . 0}$ \\
\hline 2014 & 13856.2 & 53.9 & 1707.2 & 6.6 & 0.3 & 4.0 & 9.0 & 13.2 & $\mathbf{2 5 6 8 0 . 4}$ \\
\hline
\end{tabular}

Source: compiled according to the data of the State Statistics Service of Ukraine: Structure of concluded agreements on exchanges by types of goods (services). http://www.ukrstat.gov.ua/ operativ/operativ2005/sze/sze_ric/bir/bir_u/suu_u.htm [In Ukrainian].

${ }^{34}$ Hretska N. A. Development and operation of wholesale agricultural markets in Ukraine (ukr. Rozbudova ta funktsionuvannia optovykh rynkiv silskohospodarskoi produktsii v Ukraini) / N. A. Hretska // Ekonomika APK. 2013. No. 11. p. 50. [In Ukrainian]. 
This situation leads to the fact that small and medium-sized domestic farmers experience a significant lack of infrastructure capacity to sell products. Although in the period of 2000-2017, the share of households in total agricultural production output in Ukraine decreased from 61.8 to $39.5 \%$ amid the increase in the share of non-financial corporations and the general state administration sector (Fig. 3), however, villagers and farmers now produce up to $80 \%$ of milk, $43 \%$ of meat, $95 \%$ of potatoes, $84 \%$ of other vegetables, $85 \%$ of fruits and berries ${ }^{35}$. They all need developed wholesale markets to sell agricultural products, and these needs are increasing year after year. In this context, it is worth mentioning that only about $20 \%$ of the total number of personal farms in the country are market oriented and $41 \%$ are semi-commercial small farms ${ }^{36}$.

Currently, the key problems in the functioning of domestic wholesale markets for agricultural products are clearly crystallized. It is necessary to define the following among them:

- insufficient level of congestion of wholesale market sale space;

- low level of demand for their services from customers;

- relatively high tariffs for small and medium-sized producers;

- dynamic distribution of retail turnover in wholesale markets,

- functioning as traditional consumer markets;

- significant lack of material and technical base;

- no auctioning;

- the inability to influence the amplitude of price fluctuations and to provide prompt balancing of price volatility;

- weak integration and involvement in the processes of development of supply chains in the field of purchase and sale of agricultural products.

As a result, Ukrainian agrarians are practically deprived of the ability to withstand the fierce competition with large intermediaries, which virtually monopolized most segments of the domestic food market for agricultural products, which is especially true in the context of its globalization. Therefore, primary producers receive no more than $30-40 \%$ of the total final price for manufactured products (while in developed countries it is between 50 and $70 \%{ }^{37}$ ); and its biggest share comes from the secondary market.

\footnotetext{
35 The cooperatives will give jobs to 5 million peasants. Ministry of Agrarian Policy and Food of Ukraine. http://minagro.gov.ua/node/5335 [In Ukrainian].

${ }^{36}$ Borodina O.M. Integration of small farmers into value-added agri-food chains: methodological approaches and empirical research (ukr. Intehratsiia dribnykh silskohospodarskykh vyrobnykiv do ahroprodovolchykh lantsiuhiv dodanoi vartosti: metodolohichni pidkhody ta empirychni doslidzhennia) / O. M. Borodina // Economics and forecasting (ukr. Ekonomika i prohnozuvannia). 2014. No 2. p. 82.

37 Prisyazhnyuk N. On the need and directions for deepening agrarian reform (rus. O neobkhodimosti i napravleniyakh uglubleniya agrarnoy reform) // N. Prisyazhnyuk. P. Sabluk. M. Kropivko // Economy of Ukraine (ukr. Ekonomika Ukrainy). 2011. No. 6. p. 10. [In Russian].
} 


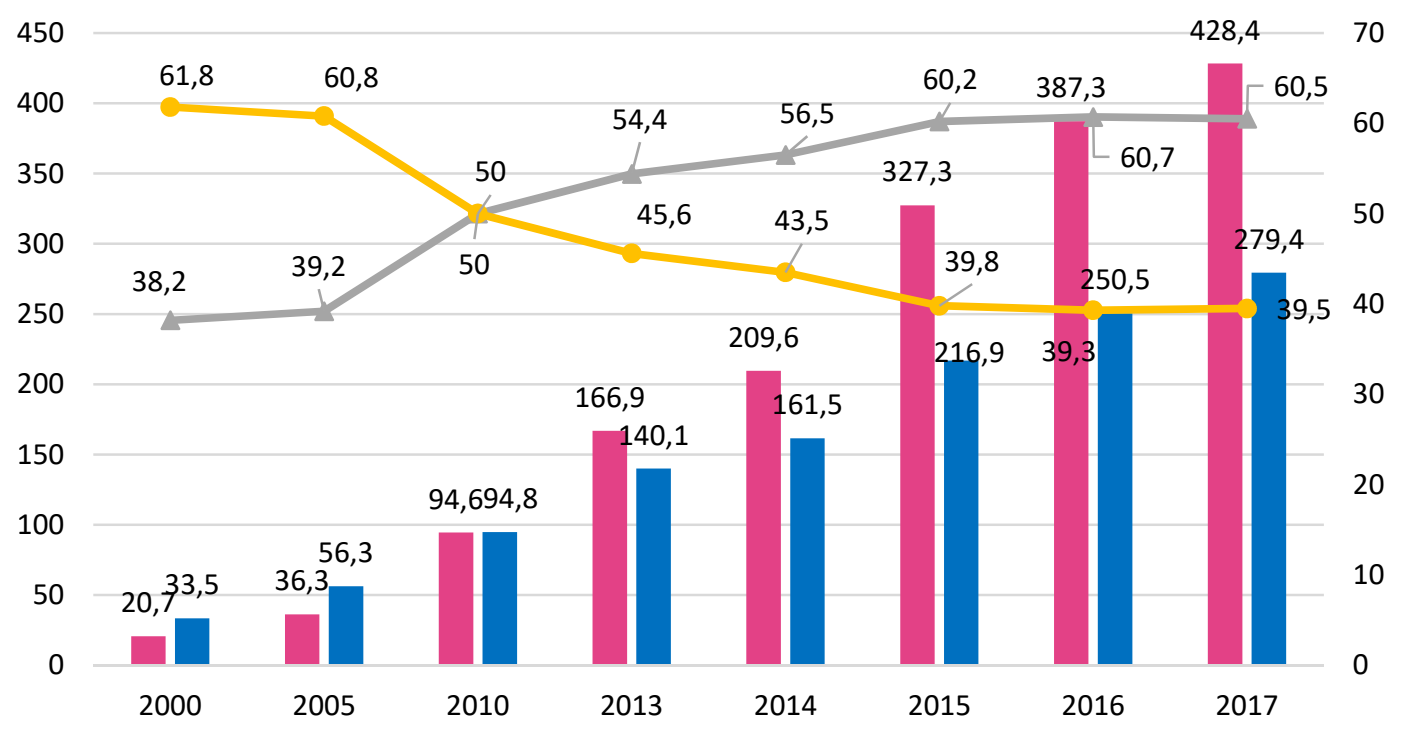

Agricultural produce output by non-financial corporations and general state administration sector, UAH billion, left scale

Agricultural production output by home farms, billion UAH, left scale

-Share of non-financial corporations and general state administration sector in gross output, $\%$ right scale

- Share of home farms in gross output,\%, right scale

\section{Fig. 3. Structure of agricultural production by major producer groups in Ukraine}

Source: compiled according to: Ukraine's agriculture in 2017. Statistical collection. State Statistics Service. K., 2018. P. 37. [In Ukrainian].

It is characterized by rather opaque sales conditions and commercial channels of purchase and sale of agricultural products, as well as fuzzy mechanisms for their price determination. This is evidenced by the high share of unofficial sales by home farms, which exceeds $80 \%$ for vegetables, $60 \%$ for meat, $40 \%$ for dairy products. The significant spread of this negative tendency is due to, first of all, a significant gap in the prices of products sold by unofficial and official sales channels. It is estimated that this gap often reaches 2.5 times for milk and beef and 4 times for vegetables ${ }^{38}$.

The sector, represented by service cooperatives, which has long

${ }^{38}$ Explanatory note to the revised draft Law of Ukraine 6490-d of 18.05.2018 "On Amendments to the Tax Code of Ukraine and Some Legislative Acts of Ukraine on Encouraging the Creation and Operation of Family Farms" http://search.ligazakon.ua/1_doc2.nsf/link1/GH50A7LA.html. [In Ukrainian]. 
proven to be highly effective in the developed countries of the world as institutional platforms for the unification of individual farms, largescale procurement and storage of agricultural products, its pre-sale processing and marketing services, is developing quite slowly. Thus, about $80 \%$ of all grain produced in Sweden is now sold through marketing cooperatives, $40 \%$ in USA, $54 \%$ in Canada and $70 \%$ in France. There are about 500 agricultural cooperatives in Canada that serve almost $2 / 3$ of the farmers ${ }^{39}$.

Unfortunately, their contribution to the development of the agrofood market infrastructure is rather small. Although in 2009-2019, especially in the last 2 years, the total number of servicing cooperatives in the agricultural sector increased almost threefold - from 496 to 1286, but the economic activities were carried out by $54 \%$, of which 25 were represented by the processing industry, procurement and marketing - 149, delivery - 16, service sphere - 101, and 298 cooperatives had multifunctional specialization. They bring together nearly 25,000 people; created over 1.6 thousand permanent jobs in rural areas; hold 21.8 thousand cattle units; sold almost 50 thousand tons of milk, about 3 thousand tons of grain, 0.2 thousand tons of meat and 3.2 thousand tons of fruit and vegetable products; and also paid total taxes and fees to the state budget for almost UAH 14 million ${ }^{40} 41$.

The underdevelopment and degradation of the cooperative segment of the domestic agrarian market and the underutilization of its potential are the reasons for the decrease in the number of people employed in the private farms in rural areas, the massive outflow of the able-bodied population, the destruction of the objects of social and engineering infrastructure. According to expert estimates, our state requires at least 18,000 service cooperatives in the field of dairy production, grain production, growing and killing of livestock, harvesting and processing of fruits, vegetables, animal foods and hay, provision of communal services. They would allow not only to integrate up to 5 million rural people into a single food chain ${ }^{42}$, but also ensure the functioning of an institutional mechanism for obtaining state support, including in the implementation of their financial leasing operations for the technologisation of the livestock production processes. To the reasons

${ }^{39}$ Baban T. O. Substantiation of efficiency of cooperation of agricultural enterprises for export of barley grain (ukr. Obgruntuvannia efektyvnosti kooperatsii silskohospodarskykh pidpryiemstv dlia eksportu zerna yachmeniu) / T. O. Baban // Scientific Journal «ScienceRise». 2017. No. 7 (36). p. 20.

${ }^{40}$ The legal field for the development of agricultural cooperation needs change / Olena Kovaleva. Ministry of Agrarian Policy and Food of Ukraine. http://www.minagro.gov.ua/node/23256. [In Ukrainian].

${ }^{41}$ Developed by the authors according to: Dynamics of development of agricultural service cooperatives for 2009-2019 Ministry of Agrarian Policy and Food of Ukraine. http://minagro.gov.ua/ministry?nid=15750 [In Ukrainian].

${ }^{42}$ The cooperatives will give jobs to 5 million peasants. Ministry of Agrarian Policy and Food of Ukraine. http://minagro.gov.ua/node/5335 [In Ukrainian]. 
that discredit the idea of cooperation and hinder the development of agricultural service cooperatives in Ukraine, belong the following:

- insufficient level of government support, in particular financial support (in 2012 - UAH 5 million, 2013 - none, only in 2018 - UAH 6.3 billion $^{43}$ was planned to support farming, but no more than UAH 3 million per cooperative $\left.{ }^{44}\right)$;

- imperfection of the regulatory framework of its regulation, dispersion, conflicts and inconsistencies of regulatory norms

- unsatisfactory condition of the objects of the economic cooperation system ${ }^{45}$

- widespread dissemination of pseudo-cooperative commercial structures and shadowing of the agrarian sector;

- deformation of the idea of agrarian cooperation by villagers.

Special attention should be paid to agricultural logistics, which is represented by logistic centers, warehouses, elevators, transportation network, etc. Unfortunately, experts state the low level of domestic farmers provision with storage facilities for the storage of fruits and vegetables, refrigeration equipment, elevators and granaries ${ }^{46}$. Almost $75 \%$ of agricultural enterprises lack technological equipment for processing vegetables, which narrows the possibilities of production of products with higher added value.

The starting point of infrastructure escalation in Ukraine should be the development of road and transport infrastructure. Currently, domestic farmers are experiencing a significant lack of quality road and rail transport services, especially during peak periods of agricultural campaigns, lack of a transparent market for agrotransportation and also they suffer from extremely poor transport services ${ }^{47}$. Although transport services account for about $12 \%$ of Ukraine's GDP, nearly $15 \%$ of total production facilities and about $6 \%$ of total labor force are concentrated here, still there is a low level of use of transit potential $(70 \%)$ and public transport potential $(50 \%)^{48}$. At the same time, despite the high share in

\footnotetext{
43 Cooperatives will receive half of the budget support for farmers. Agricultural servicing cooperative of Ukraine. NGO "Union of Participants of the JOC of Ukraine", September 20, 2017. http://www.coopunion.org.ua/?p=7826 [In Ukrainian].

44 Zhurakovska L.A. Priority directions of development of agrarian market infrastructure in Ukraine / L.A. Zhurakovska / National Institute for Strategic Studies, December 2018, P. 8. [In Ukrainian].

${ }^{45}$ Organizational and Economic Instruments of State Agrarian Policy in Ukraine: An Analytical Report / V. M. Rusan, O. V. Sobkevych, A. D. Yurchenko. K. : NISD, 2012. p. 54. [In Ukrainian].

${ }_{46}$ Zhurakovska L.A. Priority directions of development of agrarian market infrastructure in Ukraine / L.A. Zhurakovska / National Institute for Strategic Studies, December 2018, Pp. 15-16. [In Ukrainian]; Rusan V.M. Problems of development of agrarian production in Ukraine and perspective directions of utilization of the agrarian potential of the state for increasing the level of food security / V.M. Rusan. National Institute for Strategic Studies. P. 8. [In Ukrainian].

${ }_{47}$ Domestic logistics: a decrease in domestic transportation and transit cargo due to a lack of qualified specialists (results of a blitz survey of experts) // Logistics: problems and solutions. 2014. No 1. pp. 16-23. [In Russian].

${ }^{48}$ Transport and Logistics Networks of the Eastern European Economic Area: Trends, Problems and Prospects / V. A. Verhun, O. I. Stupnytskyi, M. A. Dashkuiev. Kyiv: «VADEKS», 2016. pp. 114-120. [In Ukrainian].
} 
foreign currency earnings, the share of agricultural products in the total volume of freight transportation by railway is only $11 \%$, and by road transport - 14\% ${ }^{49}$. In addition to functional moral depreciation and physical wear, often the main reasons that hamper the development of efficient logistical services for agricultural producers are the following ${ }^{50}$ :

- violation of delivery schedules of agricultural products;

- significant lack of pulling power and rolling stock;

- constantly increasing transport tariffs, including "Ukrzaliznytsia";

- increased unpredictable natural and climatic risks;

- insufficient capacity of domestic elevators;

- losses of the national marine and river fleet and port infrastructure.

The current state of agrarian logistics in Ukraine corresponds to the quantitative and structural parameters of the domestic logistics market, in which $89 \%$ are freight services, 8\% - storage (except customs clearance and automation of logistics processes), $2 \%$ - freight forwarding services, $1 \%$ supply chain management services ${ }^{51}$. The insufficient level of its development is systematically reflected in the rating of the Logistics Performance Index, which is calculated by World Bank experts (Table 4).

Table 4

UKRAINE LOGISTICS PERFORMANCE INDEX AND ITS COMPONENTS ${ }^{52}$

\begin{tabular}{|l|c|c|c|c|c|}
\hline $\begin{array}{c}\text { Indicator / Rank in World } \\
\text { Ranking }\end{array}$ & $\mathbf{2 0 0 7}$ & $\mathbf{2 0 1 0}$ & $\mathbf{2 0 1 2}$ & $\mathbf{2 0 1 6}$ & $\mathbf{2 0 1 8}$ \\
\hline Logistics Performance Index & $2.55-73$ & $2.57-105$ & $2.85-69$ & $2.74-83$ & $2.83-69$ \\
\hline Customs & $2.22-97$ & $2.02-135$ & $2.41-88$ & $2.30-116$ & $2.49-89$ \\
\hline Infrastructure & $2.35-74$ & $2.44-79$ & $2.69-70$ & $2.49-84$ & $2.22-\mathbf{1 1 9}$ \\
\hline International transportation & $2.53-83$ & $2.79-84$ & $2.72-83$ & $2.59-95$ & $2.83-68$ \\
\hline $\begin{array}{l}\text { Logistics quality and } \\
\text { competence }\end{array}$ & $2.41-90$ & $2.59-77$ & $2.85-61$ & $2.55-95$ & $2.84-61$ \\
\hline Tracking and tracing & $2.53-80$ & $2.49-112$ & $3.15-50$ & $2.96-61$ & $3.11-52$ \\
\hline Timeliness & $3.25-21$ & $3.06-114$ & $3.31-68$ & $3.51-54$ & $3.42-56$ \\
\hline
\end{tabular}

Despite some improvement in Ukraine's competitive position in 2007$2018^{53}$, it remains at a low level, almost twice inferior to the leader -

\footnotetext{
49 Transport and Communication of Ukraine 2017. Statistical collection. State Statistics Service of Ukraine. K.., 2018. pp. 44- 45. [In Ukrainian].

Domestic logistics: a decrease in domestic transportation and transit cargo due to a lack of qualified specialists (results of a blitz survey of experts) // Logistics: problems and solutions. 2014. No. 1. pp. 16-23. [In Russian].

${ }^{51}$ Transport and Logistics Networks of the Eastern European Economic Area: Trends, Problems and Prospects /

V. A. Verhun, O. I. Stupnytskyi, M. A. Dashkuiev. Kyiv: «VADEKS», 2016, 2016. p. 114. [In Ukrainian].

${ }_{52}$ LPI Global Ratings 2018. https://lpi.worldbank.org/international/global/2018.

53 Ibid.
} 
Germany (4.20 in 2018) ${ }^{54}$. In particular, the domestic grain sector is characterized by high production losses both at the grain production stage $(2.5-5 \%$ of total volume for agricultural holdings and $10-40 \%$ for medium-sized companies) and during storage $(0.5-1.25 \%$ and 5 $10 \%$ respectively $)^{55}$. A similar situation is observed with other types of agricultural products with the greatest losses in the segment of small producers who are unable to provide themselves with infrastructure. Ukraine's involvement in the Pan-European transport corridor system can be used to form such chains.

Agrarian infrastructure can increase the economic efficiency of agricultural production. Losses of agricultural products at various links in the food chain reach 20 USD for each tone of agricultural produce, or USD 600 million per year, taking into account the current export volumes of domestic agrarians to the world markets ${ }^{56}$. According to the experience of the countries of Western Europe and North America, the development of the transport and logistics sector allows to reduce the costs of loading and unloading operations by $15-20 \%$ while maintaining material flow and to accelerate the turnover of material resources by 20 $40 \%$ and reduction of their storage by $50-200 \% 57$.

\section{Conclusion}

The development of global, international and national markets is uneven, one of the factors of this is the state availability of appropriate infrastructure. This results to the fact that countries, that have not developed infrastructure at the national level, had ineffective strategies, and refused to invest into realization of innovative solutions, lose competitive positions in international markets. These countries often have to take advantage of foreign opportunities by financing their development and diverting resources from national infrastructure.

Summarizing, we state that the current state of the agroindustrial complex of Ukraine infrastructure in terms of most quantitative and qualitative parameters is significantly inferior if it is compared to the world standards. The domestic agrarian infrastructure partly fulfills its main functions to ensure the effective integration of the subsystems of the national food chain and its organic incorporation into the global

\footnotetext{
54 Ibid.

55 Themen D. Food Losses and Waste in Ukraine. Country Report, 2013. P. 1.

56 Vostryakova V.I. The urgency of implementing the concept of agro-food supply chain management to minimize losses of agricultural enterprises / V.I. Vostryakova // Scientific Bulletin of Uzhgorod National University (ukr. Naukovyi visnyk Uzhhorodskoho natsionalnoho universytetu). 2016. No. 7. Vol. 1. p. 70. [In Ukrainian].

${ }^{57}$ Yatsiuta $O$. Transport-logistic system of Ukraine in the conditions of European integration (ukr. Transportnolohistychna systema Ukrainy v umovakh yevropeiskoi intehratsii) / O. Yatsiuta // Foreign Trade: Economics, Finance, Law (ukr. Zovnishnia torhivlia: ekonomika, finansy, parvo). 2016. No. 3. p. 89. [In Ukrainian].
} 
production networks, formed in the agricultural sector. The consequences of this are the deteriorating food security situation in Ukraine:

- increase of the level of the agricultural market shadowing;

- strengthening of monopolization in the agroindustrial complex by the intermediary structures in the supply and sale sphere, which are controlling the infrastructure facilities;

- slowing down the process of building a highly competitive market of agricultural products;

- preserving the high amplitude of fluctuations in the price environment for agricultural products;

- extremely inefficient use of the resource potential of the domestic agrarian sphere;

- constant increase in transaction costs of agricultural producers, processors and consumers,

- colossal losses of state and local budgets from failure to receive tax payments.

The implementation of the domestic policy of the agroindustrial complex functioning and rural areas development strategies require such theoretical concepts as critical infrastructure, infra-path, infrastructure escalation, competitive models, strategic planning and quality management. Building a highly developed and highly diversified agricultural infrastructure in Ukraine is impossible without the implementation of a set of institutional and regulatory measures, development of tools for building agrarian logistics, budget and tax incentives, quality improvement and resource filling of investment and financial infrastructure, in particular, bank lending and interest rate management for the agroindustrial sector, establishment in the structure of the banking system of a highly specialized agrarian bank and a guarantee fund of agroindustrial complex loans, instruments of agricultural receipts; improvement of technological innovation infrastructure and information support. They should not only outline the general policy framework, identify strategic priorities and approve targeted programs, but also provide systematic incentives for stakeholders to develop and implement collaborative efforts, to conduct and support education policies and develop competitive markets and entrepreneurship.

The key priorities include accelerated development of the institutional infrastructure of the domestic agrarian market, especially the exchange segment and the system of agricultural service cooperatives and agrarian logistics. Particular attention should be paid to the support of the interinstitutional cooperation development in accordance with the provisions of the concept of the triple helix (authorities - producers - higher education institutions), which should lead to the formation of effective economic 
models of extended infrastructure reproduction. At the same time, both local and global trends in digitization, networking and clustering, formation of global chains, prioritization of sustainable development and European vector of Ukraine's participation in global integration processes should be taken into account.

\section{References}

1. A guide to Healthy food Markets. World Health Organization. 2006. https://apps.who.int/iris / bitstream/handle/10665/43393/9241593938_eng.p df; jsessionid=DFBA9747A8A503B9EABE2F4527CA5C75? sequence=1.

2. Agriculture of Ukraine in 2009. Statistical collection. State Statistics Committee of Ukraine. K., 2010. p. 38. [In Ukrainian].

3. Agriculture of Ukraine in 2017. Statistical collection. State Statistics Service. K., 2018. p. 37. [In Ukrainian].

4. Akaev A. Economic potential of breakthrough technologies and its social consequences. A. Akaev, A. Rudskoi. in "Industry 4.0: Entrepreneurship and Structural Change in the New Digital Landscape". ed. T.Devezas, J.Leitao, A. Sarygulov. Springer. 2017. Pp.13-41.

5. Baban T. O. Substantiation of efficiency of cooperation of agricultural enterprises for export of barley grain (ukr. Obgruntuvannia efektyvnosti kooperatsii silskohospodarskykh pidpryiemstv dlia eksportu zerna yachmeniu) / T. O. Baban // Scientific Journal «ScienceRise». 2017. No. 7 (36). p. 20.

6. Borodina O.M. Integration of small farmers into value-added agri-food chains: methodological approaches and empirical research (ukr. Intehratsiia dribnykh silskohospodarskykh vyrobnykiv do ahroprodovolchykh lantsiuhiv dodanoi vartosti: metodolohichni pidkhody ta empirychni doslidzhennia) / O. M. Borodina // Economics and forecasting (ukr. Ekonomika i prohnozuvannia). 2014. No 2. p. 82.

7. Connecting to Compete 2018: Trade Logistics in the Global Economy. The Logistics Performance Index and Its Indicators. ed. Jean-Franzois Arvis etc. The International Bank for Reconstruction and Development, The World Bank. 2018. 82 p. https://openknowledge.worldbank.org/bitstream/handle / 10986/ 29971 LPI2018.pdf.

8. Cooperatives will receive half of the budget support for farmers. Agricultural servicing cooperative of Ukraine. NGO "Union of Participants of the JOC of Ukraine", September 20, 2017. http:/ / www.coop-union.org.ua/?p=7826 [In Ukrainian].

9. Domestic logistics: a decrease in domestic transportation and transit cargo due to a lack of qualified specialists (results of a blitz survey of experts) Logistics: problems and solutions. 2014. No 1. pp. 16-23. [In Russian].

10. Dynamics of development of agricultural service cooperatives for 2009-2019 Ministry of Agrarian Policy and Food of Ukraine. http://minagro.gov.ua/ ministry?nid=15750 [In Ukrainian].

11. Dziubenko T. H. Ukrainian grains market infrastructure and logistics development (ukr. Rozvytok infrastruktury ta lohistyky zernovoho rynku Ukrainy) $/$ T. H. Dziubenko / / Ekonomika APK. 2014. No. 9. - p. 64. [In Ukrainian].

12. Explanatory note to the revised draft Law of Ukraine 6490-d of 18.05.2018 "On Amendments to the Tax Code of Ukraine and Some Legislative Acts of 
Ukraine on Encouraging the Creation and Operation of Family Farms" http: / / search.ligazakon.ua/1_doc2.nsf/link1/GH50A7LA.html. [In Ukrainian].

13. Food Outlook: Biannual report on global food markets. UN Food and Agrilculture Organization. http: / / www.fao.org/3/ca4526en/ca4526en.pdf.

14. Food resources market in the food security system of the Far East (rus. Rynok prodovolstvennykh resursov v sisteme obespecheniya prodovolstvennoy bezopasnosti Dalnego Vostoka): monograph / A.V. Ulezko. L.L. Pashina. Voronezh: FGBOU VPO Voronezhskiy GAU. 2014. 291 p. [In Russian].

15. Fosu, K.Y. Public Goods and Services and Food Security: Theory and Modelling Approaches with Special Reference to Ghana and Burkina Faso / Fosu, K.Y., N. Heerink, K.E Jhoudo, M. Kuiper and A. Kuyvenhoven. Paper presented at SADACC Seminar, 13-15 March, 1995. Accra, Ghana. 46 p.

16. Gross domestic product. Ministry of Finance. https://index.minfin.com.ua/ en / economy / gdp / [In Ukrainian].

17. Gunaratne S. A. Prospects and limitations of world system theory for media analysis: The Case of the Middle East and North Africa / / Gazette. vol. 63(2-3). Pp. 121-148.

18. Hirooka M. Innovation dynamism and economic growth: A nonlinear perspective. Edward Elgar Publishing, 2006. 448 p.

19. Hirschman, Albert O. The Strategy of Economic Development, Yale University Press, New Haven, CT. 1958. 230 p.

20. Hretska N. A. Development and operation of wholesale agricultural markets in Ukraine (ukr. Rozbudova ta funktsionuvannia optovykh rynkiv silskohospodarskoi produktsii v Ukraini) / N. A. Hretska / / Ekonomika APK. 2013. No. 11. p. 50. [In Ukrainian].

21. Intodia V. Investment in Agricultural Marketing and Market Infrastructure - A Case Study of Bihar. National Institute of Agricultural Marketing. Research Report. 2011-12. - 77 p. https://www.ccsniam.gov.in/ images /pdfs / Final_report_of_Bihar_research_study.pdf

22. Ickowitz A. Agricultura intensification, dietary diversity, and markets in the global food security narrative / A. Ickowitz, B. Powell, D. Rowland, A. Jones, T. Sunderland //Global Food Security. 20. 2019. P. 9-16.

23. Jalan J., Ravallion M. Geographic poverty traps? A micro model of consumption growth in rural China / J. Jalan, M. Ravallion / / Journal of Applied Econometrics. 2002. 17(4). Pp. 329-346.

24. Jaradat R. Fragility of oil as a critical infrastructure problem. R.M. Jaradat, C.B. Keating / / International journal of critical infrastructure protection. 2014. No.7. pp.86-99.

25. Kaira Z.S. Economic Geography: Theory and Practice (ukr. Rozmishchennia produktyonykh syl: teoriia ta praktyka): navch. posibnyk / Z. Kaira. Donetsk: Alfa-pres, 2006. 320 p.

26. Kravchuk N. I. Infrastructural background for ensuring the competitive development of the agricultural production (ukr. Infrastrukturne zabezpechennia konkurentospromozhnosti silskohospodarskoho vyrobnytstva / N. I. Kravchuk / / Stalyi rozvytok ekonomiky. Mizhnarodnyi naukovo-vyrobnychyi zhurnal. 2013. No. 4 (21). p. 227. [In Ukrainian].

27. Laranja M. Policies for science, technology and innovation: Translating rationales into regional policies in a multi-level setting / M. Laranja, E. Uyarra, K. Flanagan / / Research Policy. 2008. No. 37. Pp.823-835.

28. Logistics Performance Index Dataset. World bank. 16-05-2019. https:// lpi.worldbank.org / sites/default/files/International_LPI_from_2007_to_2018.xlsx 
29. LPI Global Ratings 2018. https://lpi.worldbank.org/international/ global / 2018 .

30. Maslak O. Agroindustry Budgeting - 2017 (ukr. Biudzhetuvannia ahrovyrobnytstva - 2017) / O. Maslak / / Propozytsiia. 07.01.2017. http:// propozitsiya.com/ua/byudzhetuvannya-agrovyrobnyctva-2017 [In Ukrainian].

31. Marocchino C. A guide to upgrading rural agricultural retail markets Cecilia Marocchino. UN Food and Agriculture Organization. 2009. 60 p. http:// www.fao.org/fileadmin/user_upload/ags/publications/AGSF_WD_24.pdf

32. McKinsey Global Institute, Infrastructure Productivity: How to Save \$1 Trillion a Year, January 2013. - 100 p. https:/ /www.mckinsey.com/ / media/McKinsey / Industries / Capital\%20Projects\%20and\%20Infrastructure / Our \%20Insights / Infrastructure\%20productivity / MGI\%20Infrastructure_Full\%20repor t_Jan\%202013.ashx

33. Networks and markets. S.Rauch, A.Cassella (eds). N.Y., 2001. 346 p.

34. Odnoroh M. A. Investment provisioning in agricultural sector of Ukrainian economy (ukr. Investytsiine zabezpechennia u silskohospodarskomu sektori ekonomiky Ukrainy) / M. A. Odnoroh / / Naukovyi visnyk Polissia. 2016. No. 4 (8). Ch. 1. p. 144. [In Ukrainian].

35. Organizational and Economic Instruments of State Agrarian Policy in Ukraine: An Analytical Report / V. M. Rusan, O. V. Sobkevych, A. D. Yurchenko. K. : NISD, 2012. p. 54. [In Ukrainian].

36. Papageorgiou A. Agricultural equipment in Greece: Farm machinery management in the era of economic crisis // Agriculture and Agricultural Science Procedia: Farm Machinery and Processes Management in Sustainable Agriculture, 7th International Scientific Symposium. No. 7. 2015. Pp. $198-202$.

37. Prisyazhnyuk N. On the need and directions for deepening agrarian reform (rus. O neobkhodimosti i napravleniyakh uglubleniya agrarnoy reform) / $\mathrm{N}$. Prisyazhnyuk. P. Sabluk. M. Kropivko / / Economy of Ukraine (ukr. Ekonomika Ukrainy). 2011. No. 6. p. 10. [In Russian].

38. Rasmussen H. O. The Global Organic Food Market and Transformation. A Conceptual Theoretical Framework. 2008. 40 p. http://orgprints.org/ 14866/1/14866.pdf.

39. Rays M. Borders of borderless enterprises (rus. Granitsy bezgranichnykh predpriyatiy) / M. Rays / / Problems of management theory and practice (rus. Problemy teorii i praktiki upravleniya). 1997. No. 1, pp. 92-97. [In Russian].

40. Rusak D. International Corporate Networks in Contemporary Geoeconomic Environment (ukr. Mizhnarodni korporatyvni merezhi v suchasnomu heoekonomichnomu prostori) : Monograph / Denys Rusak. Kyiv: ADEF-Ukraina, 2018. 408 p. [In Ukrainian].

41. Rusan V.M. Problems of development of agrarian production in Ukraine and perspective directions of utilization of the agrarian potential of the state for increasing the level of food security / V.M. Rusan. National Institute for Strategic Studies. P. 8. [In Ukrainian].

42. Samet R.H. Complexity science and theory development for the futures field // Futures, No. 44. Elsevier. 2012. - pp.504-513.

43. Satish P. Rural Infrastructure and Growth: An Overview. / P. Satish / / Indian Journal of Agricultural Economy. Jan.-March 2007. Vol. 62, No.1. Pp.32-51.

44. Shepherd B. Infrastructure, trade facilitation, and network connectivity in Sub-Saharan Africa / B. Shepherd // Journal of African Trade. 2016. 3. Pp. 1-22. 
45. Taalbi J. What drives innovation? Evidence from economic history / Josef Taalbi / / Research Policy. No. 46. 2017. pp.1437-1453.

46. The cooperatives will give jobs to 5 million peasants. Ministry of Agrarian Policy and Food of Ukraine. http://minagro.gov.ua/node/5335 [In Ukrainian].

47. The Global Competitiveness Index 2018. World Economic Forum. http: / /www3.weforum.org/docs /GCR2018/05FullReport/TheGlobalCompetit ivenessReport2018.pdf

48. The legal field for the development of agricultural cooperation needs change / Olena Kovaleva. Ministry of Agrarian Policy and Food of Ukraine. http: / / www.minagro.gov.ua/node/23256. [In Ukrainian].

49. Themen D. Food Losses and Waste in Ukraine. Country Report, 2013. P. 1.

50. Transport and Logistics Networks of the Eastern European Economic Area: Trends, Problems and Prospects / V. A. Verhun, O. I. Stupnytskyi, M. A. Dashkuiev. Kyiv: «VADEKS», 2016. pp. 114-120. [In Ukrainian].

51. Transport and Communication of Ukraine 2017. Statistical collection. State Statistics Service of Ukraine. K., 2018. pp. 44- 45. [In Ukrainian].

52. Ukraine's agriculture in 2017. Statistical collection. State Statistics Service. K., 2018. P. 37. [In Ukrainian].

53. Vostryakova V.I. The urgency of implementing the concept of agro-food supply chain management to minimize losses of agricultural enterprises / V.I. Vostryakova / Scientific Bulletin of Uzhgorod National University (ukr. Naukovyi visnyk Uzhhorodskoho natsionalnoho universytetu). 2016. No. 7. Vol. 1. p. 70. [In Ukrainian].

54. Warner M. Market-oriented agricultural infrastructure: appraisal of publicprivate partnerships / M. Warner, D. Kahan, S. Lehel / Agricultural Management, Marketing and Finance: Occasional Paper. FAO. 2009. No. 23. 185 p.

55. Williamson O. Transaction Cost Economics and Organization Theory Oliver Williamson Journal of Industrial and Corporative Change. 1993. Volume 2, Issue 2. pp.107-156.

56. Wolfert S. Big Data in Smart Farming - A review / S. Wolfert, L. Ge, C. Verdouw, M.-J. Bogaardt // Agricultural Systems. 2017. No. 153. Pp. 69-80.

57. Works, alliances and partnerships in the innovation progress. S. de la Mothe, A.Link (eds). Boston, 2002. 312 p.

58. Yatsiuta O. Transport-logistic system of Ukraine in the conditions of European integration (ukr. Transportno-lohistychna systema Ukrainy v umovakh yevropeiskoi intehratsii) / O. Yatsiuta //Foreign Trade: Economics, Finance, Law (ukr. Zovnishnia torhivlia: ekonomika, finansy, pravo). 2016. No. 3. p. 89. [In Ukrainian].

59. Zhupanenko V. M. Modern Definition of Economic Infrastructure (ukr. Suchasne traktuvannia infrastruktury ekonomiky / V. M. Zhupanenko / / Accounting and Finance in Agrobusiness (ukr. Oblik i finansy APK). 2010. No. 3. pp. 129-138. [In Ukrainian].

60. Zhurakovska L.A. Priority directions of development of agrarian market infrastructure in Ukraine / L.A. Zhurakovska / National Institute for Strategic Studies, December 2018, P. 8. [In Ukrainian].

The article was received by the Editorial Board on August 01, 2019. 